\title{
Generációs különbségek a magyar médiafogyasztásban
}

Tanulmányunkban egy 2015 áprilisi, 18 évnél idősebb internetezők körében végzett kutatás eredményeit mutatjuk be. A kutatás fókuszában a fiatalok (18-29 évesek) médiafogyasztási, internetezési és egyéb kapcsolódó szokásainak vizsgálata állt, illetve annak összevetése a 30-39 évesekével, valamint a 40 évesekével és annál idősebbekével. A kutatás eredménye szerint mind az érdeklődési körök, mind az információs csatornák használatában sajátos generációs különbségek figyelhetők meg idehaza. Bár a közösségi oldalakon összességében hasonló tényezőket tartanak fontosnak a különböző életkori csoportokba tartozó netezők, vannak eltérések abban, hogy a közösségi oldalak melyik funkcióját preferálják jobban. Az okostelefon birtoklásban, használatban, app-letöltésben, illetve használatban is érdemi generációs különbségeket találtunk.

Kulcsszavak: fiatalok, generációk, Magyarország, felmérés, médiafogyasztás, internet, közösségi média, megosztás, okostelefon

\section{Szerzői információ:}

Dr. Hack-Handa József szociológus, társadalomkutató, jelenleg a TFSZ Kft. senior kutatója. 2011-2013 között a Budapesti Gazdasági Főiskola Külkereskedelmi Karának adjunktusa, majd docense. 2006-2010 között az Ipsos Véleménykutatási Osztályának kutatásvezetôje, közben megbízott előadó az ELTE Társadalomtudományi Karán szociológia és politikaelmélet szakon. Fő kutatási területei a racionális döntések elmélete, valamint az elő́téletek szerepe és az együttmúködés lehetốségei, illetve az azt gátló tényezók, gazdasági területen interkulturális komparatív elemzések szerzóje.

Dr. Pintér Róbert a Corvinus Egyetem Infokommunikációs Tanszékének adjunktusa és az eNET Internetkutató és Tanácsadó Kft. mobil kutatásokért és e-kereskedelemért feleloos kutatásvezetôje. 2008-2012 között az Ipsos online stratégiai igazgatója, majd ügyfélkapcsolati igazgatója Magyarországon, Csehországban és Oroszországban. 2008-ig a Budapesti Múszaki és Gazdaságtudományi Egyetemen múködő Információs Társadalom- és Trendkutató Központ munkatársaként dolgozott. 1999 óta foglalkozik az információs társadalom és az internet jelenségeinek kutatásával, számos tanulmány szerzóje. Az Információs Társadalom folyóirat egykori fószerkesztốje (2005-2008), jelenleg a szerkesztóbizottság tagja.

Így hivatkozzon erre a cikkre:

Hack-Handa József, Pintér Róbert. „Generációs különbségek a magyar médiafogyasztásban”. Információs Társadalom XV, 2. szám (2015): 7-17.

$\Longrightarrow$ https://dx.doi.org/10.22503/inftars.XV.2015.2.1




\section{Hack-Handa József - Pintér Róbert}

\section{Generációs különbségek a magyar médiafogyasztásban}

\section{Bevezetés}

A fiatalok az olthatatlan információ- és ingerigényüket ma leginkább az internet nyújtotta szinte korlátlan világban tudják kiélni. Filmek, zene, ismeretterjesztés - mindez megtalálható számukra az interneten, részben a közösségi oldalak révén. A kommunikációs csatornák hangsúlyai is egyértelmúen az online világ felé tolódnak el. De kétségbeesni nem érdemes: a mai fiatalok egyszerúen ugyanannyira kíváncsiak, és valószínúleg ugyanarra, mint a szüleik voltak - csak nekik már van internet-hozzáférésük.

Az eNET Internetkutató Kft. a Hírközlési és Informatikai Tudományos Egyesülettel (HTE), valamint a Schönherz Iskolaszövetkezettel közösen 2015 áprilisában készített a szerzók vezetésével online kérdőíves kutatást az internetezó fiatalok és idősebbek médiafogyasztási, illetve egyéb szokásairól. ${ }^{1}$ Jelen tanulmány ennek a kutatásnak a generációs különbségekre vonatkozó fontosabb eredményeit összegzi, és vonja le a tanulságokat azokból.

\section{Generációs különbségek nyomában}

Az emberiség kommunikációs receptjei egy folyton változó étlapot eredményeznek, amelynek elemeit a különbözố generációk különbözó lelkesedéssel fogyasztják, a tamtam dobok üteme például kevésbé hoz lázba ma egy 19 éves szerelmes fiatalt, mint egy Viberen kapott smiley-jel. Ha bármelyik generációnak nem érthetó az állítás egyik fele, akkor csak újabb igazolást nyert, hogy a generációk között különbségek vannak a kommunikációban, a médiafogyasztásban, és feltehetôen még az élet számos más területén. Jelen cikk nem vállalkozik mindezen különbségek elemzésére, hanem egy még vélelmezhetôen közös platform, a nyomtatott betúk nyelvén számol be arról, hogy miként használják az internetet és hogyan fogyasztanak médiát a fiatalok (18-29 évesek), a középgenerációba tartozók (30-39 évesek) és az idősebbek (40+) 2015-ben Magyarországon.

Létezik egy generációs elmélet, amelyet érdemes kiindulásképpen körbejárni a fiatalok és más generációk médiafogyasztása kapcsán. Ennek legpopulárisabb kifejtése a Strauss - Howe szerzópároshoz köthetố (Howe-Strauss, 1991). Az elmélet szerint születési idejük alapján generációkba lehet csoportosítani az amerikai embereket, és ezek a generációk alapvetố tulajdonságokban térnek el egymástól. A jelenlegi generációk az Egyesült

${ }^{1}$ A kutatás 1037 fố megkérdezésével folyt a Véleményem Van (Veva.hu) online kutatási közösség tagjainak körében. Az adatok nem, kor és régió alapján reprezentálják a 18 évnél idôsebb hazai internetezók véleményét. A szerzốk ezúton szeretnének köszönetet mondani a HTE-nek és a Schönherz Iskolaszövetkezetnek, hogy hozzájárulásukat adták a kutatási adatok tudományos célú felhasználásához és publikálásához. 
Államokban a Csendes generáció (1925-1942 között születettek), a Baby Boomerek (1943-1960), az X generáció (1961-1981), az Y (vagy más néven millenniumi) generáció (1982-1995²), végül a Z-generáció (1995-2010).

Miközben az elmélet megtermékenyítô lehet a gondolkodás számára, fontos észben tartani, hogy ez egy amerikai korszakolás, amitól lehetnek sajátságos hazai eltérések (lásd például Székely, 2014)- ezért nem is ragaszkodtunk hozzá mereven a kutatás megtervezésekor és az eredmények lentebbi ismertetésekor. A kutatási eredmények elemzése során inkább azt a kézenfekvố megoldást választottuk, hogy a különbözố életkori csoportokat (18-29 évesek, 30-39 évesek és 40 évesek, illetve annál idôsebbek) hasonlítottuk össze egymással. Így lényegében nem a fentebb bemutatott generációs elmélet által meghatározott korosztályokat hasonlítottuk össze egymással, ebben az esetben ugyanis az 55-72 éves Baby-boomereket, a 34-54 éves X generációt, a 20-33 éves Y generációt és az 5-20 éves Z-generációt kellett volna összehasonlítanunk. Viszont az 5-20 évesekre vonatkozóan nem rendelkeztünk elég adattal, mivel az Európai Uniós adatvédelmi szabályozás jelentôsen megnehezíti a 16 évnél fiatalabbak toborzását egy online panelbe, amelyen a kutatásunk folyt. További korlátozás lett volna a generációs elmélet követésében, hogy az 55-72 éves korosztályra egy pusztán interneten folyó online kutatásból nem igazán lehetett volna érvényes következtetéseket levonni, mivel idehaza az életkor elórehaladtával jelentősen csökken az internetezók aránya, így az internetezó idôsek nem igazán reprezentálják a teljes korosztályukat.

Egyébként is szkeptikusak vagyunk, hogy a népszerú Howe-Strauss-féle, szerintünk félig-meddig áltudományos megközelítés mennyire érvényes idehaza. Bár empirikus adatokkal nem rendelkezünk, de azt gondoljuk, hogy Magyarországon feltehetôen mások azok a meghatározó élmények, történések, jellemzók, amelyek generációs törésvonalakat voltak képesek létrehozni. Ha politikai eseményeket keresnénk, akkor ilyen lehetne például az 1956-os forradalom, vagy 1968 és annak reform szellemisége, a '80-as évek demokratikus ellenállása vagy éppen a rendszerváltás és szubjektív megélése. Azok a fiatalok például, akik az 1990-es évek legelején léptek be a munkaerópiacra, gyorsan emelkedhettek fel és mind a mai napig meghatározó szerepet tölthetnek be számos tekintetben. Ugyanakkor napjaink magyar fiataljai számára sokkal inkább meghatározó a 2008-ban kibontakozó gazdasági, majd politikai válság és a „menjek vagy maradjak” dilemmának a megélése, ami idôvel szintén generációs törésvonallá válhat.

De nem csak politikai események határoztak meg idehaza generációkat, sốt. A generáció kifejezés már évtizedekkel ezelótt beszivárgott a populáris magyar kultúrába és a társadalmi közbeszédbe, amit jól mutat például a „Nagy generáció” ${ }^{3}$ és a „kis generáció”4 fogalmának széleskörú elterjedése és használata. Míg elóbbi a ma '50-60 éves, 1960-as években lázadó fiatalokra és az ô élményeikre utal, utóbbi az ố gyerekeikre, a '80-as években felnövő fiatalokra, akik nehezen találták a helyüket, részben szüleik árnyékában.

\footnotetext{
${ }^{2}$ Egymásnak ellentmondó korszakolások olvashatók különbözô adaptációkban, így a szakaszhatárokat érdemes rugalmasan kezelni.

${ }^{3}$ A nagy generáció életélményeiról, sorsáról és részben megalkuvásairól lásd a Nagy generáció címú, 1985-ben készült magyar filmet (http://www.imdb.com/title/tt0089663).

${ }^{4}$ „Jó a helyzetünk / A hírek most is erról szólnak / És ezt hinni volna jó. / De féló, hogy felnövünk, / És senki,senki nem tud róla, / Hogy élt itt egy kis generáció.” Részlet az Elsố Emelet együttes: Kis generáció c., 1990-ben megjelent számából.
} 
Viszont lehetôségünk van még messzebb visszamenni az idóben. A közös élmények összekovácsoló erejére, a sajátos kelet-európai és azon belül a magyar generációs élményekre példa a Magyarországon „elhíresült” „hanyas vagy...” kérdés, illetve az arra adott válasz: „Mi félszavakból megértjük egymást”. Szilágyi György írása 1976. december 3-án hangzott el elôször a Kossuth Rádióban, és a '28-asok életre szóló élményeit sorolta fel, ami egybekovácsolta és el is taszította egymástól a nemzedék tagjait:

„Nincs még egy nemzedék, amelynek tagjai ilyen messzire kerïltek egymástól.

Felszeletelt bennünket a történelem, mint cukrász a tortát.

De aะ igazak nem vesztették szem elól egymást.

Mint ahogy a gazemberek is egymásra találtak.

Valamennyien'28-asok.

Kivégæók és kivégzettek.

Bünösök és ártatlanok.

Sokan indultunk, kevesen maradtunk.

Az arcunkra volt irva a holnap.

A háború nyelvén beszéltuink, de megértettük egymást.

Hanyas vagy? "28-as? Mi félszavakból megértjuik egymást."

(Szilágyi, 1976)

Szilágyi mellbevágó írása - aminek el- és újraolvasását melegen javasoljuk mindenkinek - azóta is megihleti azokat, akik megismerik. Egyik leghíresebb feldolgozása Nagy Bandó Andrásé, aki az 1947-esekre (a fentebb említett nagy generáció) adaptálta a szöveget, aminek mottója: „mi félszavakból sem értjük meg egymást” (Nagy Bandó, 1986).

$\mathrm{Na}$, de milyenek a mai fiatalok? A mostani fiatalok jellemzése kapcsán érdemes a Magyar Ifjúság 2012 kutatás eredményeit felidézni - a kutatás a 15-29 éves magyar fiatalokat „új csendes generációként” jellemezte, amellyel befelé forduló, óvatos, visszahúzódó magatartásukat jellemezte (Székely, 2013).

Ezek az elméleti, részben földrajzilag és kulturálisan is távoli helyekre vonatkozó elgondolások és a hazai, tömegkulturális vonatkoztatási keret, valamint az empirikus kutatások némi támpontot nyújthatnak a jelen kutatás során használt adatok értelmezéséhez, bár ezek használatával sem spórolható meg az adatok kritikus elemzése és interpretációja. A fenti elméletek inkább kiegészítésül, a megértést és az eredmények kontextusba helyezését lehetôvé tevő keretként szolgálhatnak az olvasó számára.

\section{Kíváncsi huszonévesek, családalapító fiatalok, ínyenc érettek}

Csak az érdeklődési körök alapján nem érdemes generációs szakadékokat vizionálni az internetezók között, de nehéz nem észrevenni az eltérô hangsúlyokat a vizsgált korosztályok - 18-29 évesek, 30-39 évesek és 40 évesek, illetve idősebbek - között. A kutatás során 24 különbözố téma közül választhatták ki a megkérdezettek a számukra legérdekesebbeket.

A legfiatalabbak körében a kép és hang „mindent visz”, listájuk elsô helyén a filmek és mozi, második helyén a zene szerepel. De mielốtt valaki öncélú szórakozással vádolná 
a 30 év alattiakat, érdemes észrevenni, hogy listájuk harmadik helyén a tudományos, ismeretterjesztố tartalmak állnak - elókelóbb helyen, mint az idősebb korosztályok körében. Fontos még az is, hogy egyedül csak az ô esetükben került fel a TOP5-ös listára a számítástechnika, internet és informatika világa.

A 30-as korosztály egyértelmúen átmenetet képez érdeklődési körét tekintve is a fiatalabbak és a középkorúak, illetve idôsebbek között. Miközben elsố helyen náluk is még a filmek állnak, a következó helyeken már az egészség, otthon és a gasztronómia áll - mintha örökifjú lelkük a folytonos keresésból a megállapodás irányába mozdult volna el.

Nem hiába, hiszen 40 év felett beköszönt az „ínyencek kora”. Ebben a korosztályban a top témák a gasztronómia és az életmód, meg persze az otthon. Érdekes módon ekkor visszatér a toplistára a tudományos, ismeretterjesztô tartalomfogyasztás is - talán egyfajta jutalmaként a megállapodásnak.

\begin{tabular}{|c|c|c|c|}
\hline Rangsor & 18-29 évesek & 30-39 évesek & 40 évesek és idősebbek \\
\hline 1. & Filmek, mozi & Filmek, mozi & Gasztronómia \\
\hline 2. & Zene & Életmód, egészség & Életmód, egészség \\
\hline 3. & $\begin{array}{l}\text { Tudományos, } \\
\text { ismeretterjesztố }\end{array}$ & Kert, ház, otthon & Kert, ház, otthon \\
\hline 4. & Életmód, egészség & Gasztronómia & $\begin{array}{c}\text { Tudományos, } \\
\text { ismeretterjesztő }\end{array}$ \\
\hline 5. & $\begin{array}{l}\text { Számítástechnika, } \\
\text { internet, informatika }\end{array}$ & Zene & Utazások, útleírások \\
\hline
\end{tabular}

1. táblázat A legfontosabb érdeklôdési körök korosztályonként Forrás: eNET online kutatás, 2015. április, VeVa online kutatási közösség, $\mathrm{N}=1037,18+$ internetezók

\section{Változó tartalomfogyasztási formák}

Nemcsak az érdeklődési körök, de az érdeklődés kielégítésére használt információs csatornák használatában is sajátos generációs különbségek figyelhetók meg idehaza. A fiatalok már egyértelmúen inkább az online világban élnek, míg a netet használó középkorosztály és az idôsebbek körében még valamelyest tartják magukat az offline média klasszikus bástyái, a televízió vezetésével.

A már internetezók bármely korosztályát vizsgáljuk, ötból négyen naponta olvasnak internetes oldalakat. Még a 40 év feletti internetezók körében sem néznek ennél nagyobb arányban tévét naponta. A fiatalabb generációk körében pedig a tévénézés térvesztése rohamosnak mondható. A 30 év alattiaknak már kevesebb mint fele néz tévét naponta saját bevallása szerint. Minél fiatalabb korcsoportot vizsgálunk, annál kisebb a rendszeresen rádiót hallgatók és a nyomtatott sajtót olvasók aránya is. Ezzel szemben a 30 év alattiak körében lényegesen nagyobb a közösségi oldalakat rendszeresen, napi szinten látogatók aránya, mint az idôsebbek körében. Nem túlzás azt állítani, hogy a közösségi oldalak átvették az elsố számú információforrás szerepét a legfiatalabbak körében minden más médiumtól. 


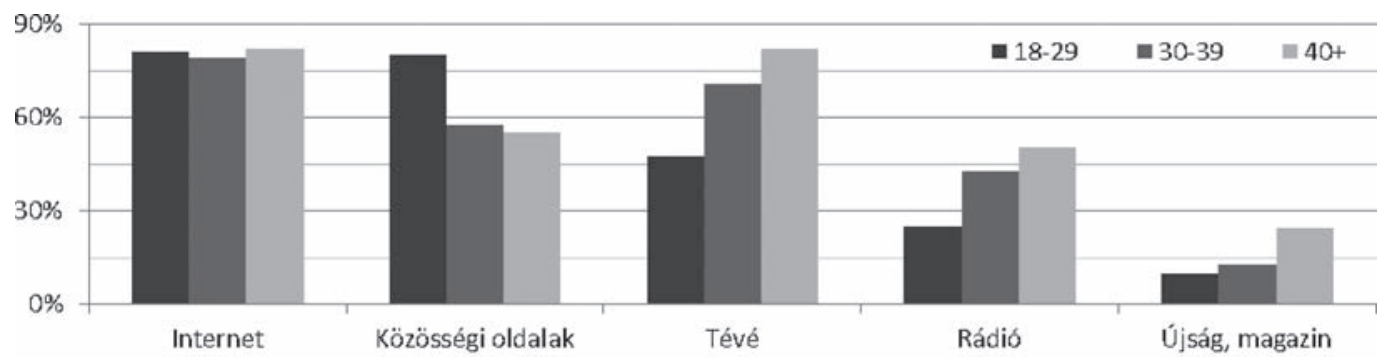

1. ábra A naponta elérhetố internetezók aránya különbözô csatornákon korcsoportonként Forrás: eNET online kutatás, 2015. április, VeVa online kutatási közösség,

$$
\mathrm{N}=1037 \text { fő, 18+ internetezók }
$$

A televíziózás és az internetezés viszonya különösen aktuális kérdés a fiatalok esetében. A tévénézés korosztályokon át a médiafogyasztás bevehetetlen bástyájának túnt. De az internetezó 30 év alatti fiatalok körében ez a pozíciója megrendült - temetni azért még korai lenne, a népesség nagyobb részét kitevő generációk még lelkesen tévéznek -, igaz, az internetezés mellett. ${ }^{5}$

\begin{tabular}{|c|c|c|c|c|c|c|c|c|}
\hline & \multicolumn{4}{|c|}{ Tévénézés gyakorisága } & \multicolumn{4}{c|}{$\begin{array}{c}\text { Internetes oldalak olvasásának } \\
\text { gyakorisága }\end{array}$} \\
\hline Korcsoport: & $\mathbf{1 8 - 2 9}$ & $\mathbf{3 0 - 3 9}$ & $\mathbf{4 0 +}$ & Átlagosan & $\mathbf{1 8 - 2 9}$ & $\mathbf{3 0 - 3 9}$ & $\mathbf{4 0 +}$ & Átlagosan \\
\hline naponta & $47 \%$ & $71 \%$ & $82 \%$ & $70 \%$ & $81 \%$ & $80 \%$ & $83 \%$ & $81 \%$ \\
\hline $\begin{array}{c}\text { hetente } \\
\text { többször }\end{array}$ & $17 \%$ & $16 \%$ & $8 \%$ & $13 \%$ & $14 \%$ & $13 \%$ & $12 \%$ & $13 \%$ \\
\hline hetente & $12 \%$ & $6 \%$ & $3 \%$ & $6 \%$ & $1 \%$ & $3 \%$ & $3 \%$ & $3 \%$ \\
\hline $\begin{array}{c}\text { havonta } \\
\text { többször }\end{array}$ & $6 \%$ & $2 \%$ & $1 \%$ & $3 \%$ & $1 \%$ & $3 \%$ & $1 \%$ & $1 \%$ \\
\hline ritkábban & $11 \%$ & $4 \%$ & $4 \%$ & $6 \%$ & $1 \%$ & $1 \%$ & $1 \%$ & $1 \%$ \\
\hline soha & $6 \%$ & $1 \%$ & $1 \%$ & $3 \%$ & $1 \%$ & $1 \%$ & $0 \%$ & $1 \%$ \\
\hline összesen & $100 \%$ & $100 \%$ & $100 \%$ & $100 \%$ & $100 \%$ & $100 \%$ & $100 \%$ & $100 \%$ \\
\hline
\end{tabular}

2. táblázat Televízió nézés és internetes oldalak olvasásának gyakorisága korcsoportonként (Százalékos megoszlások)

Forrás: eNET online kutatás, 2015. április, VeVa online kutatási közösség, N=1037, 18+ internetezók

${ }^{5}$ Fontos kiemelni, hogy jelen kutatási eredmények csak a felnốtt magyar internetezókre vonatkoznak, tehát a tévénézési és internetezési szokásokból levont következtetések is csak ebben a körben érvényesek. Az akár az internet-hozzáférés hiánya miatt, akár megszokásból nem internetezók körét a megállapítások nem érintik, de ez a kör az internet-penetráció növekedésével egyre kisebb napjainkra. Így a kutatás trendek felvázolására is alkalmas. 
Külön érdekes eredménye a kutatásnak, hogy a generációs különbségek nagyon fontosak az internetezók tévénézési szokásaiban, de egyáltalán nem számítanak az internetezési szokásaikban (legalábbis, ami a gyakoriságot illeti). A különbözô generációk között a tévénézés gyakoriságában egyértelmúen statisztikailag igazolható (szignifikáns) ${ }^{6}$ összefüggés van az idôsebb generációk javára, viszont az internetezés gyakorisága esetében nem beszélhetünk igazolható összefüggésról ${ }^{7}$, generációk közötti eltérésról.

A 18-29 éves internetezók harmada jelölte meg három kedvenc weblapja közt az index.hu-t (33\%), több mint negyedük az [origo] oldalát (27\%), minden tizenegyedik fiatal pedig a HVG weblapját (9\%). A harminc felettiek esetén a sorrend változik: az [origo] kerül az elsố helyre, másodikként az index.hu-t nevezik meg, míg harmadik helyen a startlap.hu és különbözố aloldalai végeznek.

A közösségi oldalakat használó fiatalok közt a facebook.com dominálja a piacot, melyen gyakorlatilag mindenki regisztrált már a kutatásban részt vettek közül (99\%). Egyéb közösségi oldalak (korcsoporttól függetlenül) csak alacsony arányban kerülnek említésre. A közösségi médiát döntôen kapcsolattartásra használják, másodsorban érdekes oldalak követésére: az internethasználók több mint fele ilyen módon (is) tájékozódik.

\section{Élet a közösségi oldalakon: ki, mit csinál és miért?}

A kutatás szerint a közösségi oldalak pont azt nyújtják, amit gondolunk róluk, elsô körben annak lehetốségét, hogy családtagokkal, barátokkal, ismerôsökkel osszunk meg számunkra (is) fontos személyes információkat, és kövessük mások hasonló tevékenységét - ha úgy tetszik, pletykálkodjunk. Másodsorban a közösségi oldalaknak fontos funkciója a felhasználóik szerint, hogy nem személyes, de óket érdeklő témákat kövessenek, közösségi oldalak segítségével tájékozódjanak.

Más, a közösségi oldalakon elérhetố funkciók ugyan nem ennyire gyakran használtak az internetezók körében, de szó sincs arról, hogy érdektelenek lennének. A magyarországi internethasználók egyötöde szokott megosztani tágabb ismeretségi körében számára érdekes dolgokat. De nem ritka a karrierépítéssel, munkahelykereséssel kapcsolatos internethasználat sem a közösségi oldalakon.

Mivel az internetezók mindössze 7\%-a nem látogat egyáltalán közösségi oldalakat, tehát a közösségi oldalakat látogatók szinte lefedik a magyarországi internetezóket, érdemi eltérés nincs az internetezók és a közösségi oldalak látogatóinak véleménye között. Tájékoztató jelleggel ugyanakkor mégis megadjuk a válaszokat mindkét csoportra. Az eltérések mértéke csekély, az az adatok interpretációját nem befolyásolja, csak arra szolgál, hogy a két populáción belül is értelmezhetóek legyenek az adatok.

${ }^{6} \mathrm{p}<0,0005$

${ }^{7}$ p >0,05 (A Pearson-féle khí-négyzet teszthez tartozó szignifikancia érték 0,29.) 


\begin{tabular}{|c|c|c|}
\hline & $\begin{array}{c}\text { Magyarországi } \\
\text { felnőtt internetező } \\
\text { lakosság } \\
(\mathrm{N}=1037)\end{array}$ & $\begin{array}{c}\text { Magyarországi felnôtt } \\
\text { internetező és közösségi } \\
\text { oldalakat látogató lakosság } \\
(\mathrm{N}=963)\end{array}$ \\
\hline $\begin{array}{l}\text { családtagokkal, barátokkal, ismerósökkel való } \\
\text { kapcsolattartás személyes információk } \\
\text { megosztásán és követésén keresztül }\end{array}$ & $83 \%$ & $89 \%$ \\
\hline $\begin{array}{l}\text { követem a számomra érdekes témákkal } \\
\text { foglalkozó oldalakat, tájékozódom ezeken }\end{array}$ & $57 \%$ & $61 \%$ \\
\hline $\begin{array}{c}\text { tágabb körben megosztani a számomra } \\
\text { érdekes dolgokat }\end{array}$ & $19 \%$ & $21 \%$ \\
\hline szakmai kapcsolatok építésére, fenntartására & $16 \%$ & $17 \%$ \\
\hline szakmai tájékozódásra & $12 \%$ & $13 \%$ \\
\hline $\begin{array}{l}\text { jelenlegi/késóbbi álláskeresésre, vagy, hogy } \\
\text { ott megtaláljanak állásajánlattal }\end{array}$ & $12 \%$ & $12 \%$ \\
\hline
\end{tabular}

3. táblázat „Milyen célra használja a közösségi oldalt, oldalakat?”

Forrás: eNET online kutatás, 2015. április, VeVa online kutatási közösség,

N=1037, 18+ internetezók; az egyes funkciókat használók százalékos aránya a felnôtt magyar internetezók körében és a közösségi oldalakat látogató internetezốk közében

Bár összességében hasonló tényezóket tartanak fontosnak a különbözó életkori csoportokba tartozó netezók, vannak eltérések abban, hogy a közösségi oldalak melyik funkcióját preferálják jobban vagy kevésbé más korcsoportokhoz viszonyítva.

Úgy túnik, a családtagokkal, barátokkal, ismerôsökkel való kapcsolattartás a 40 év alattiak számára fontosabb, mint az idôsebb generációkban, feltehetốen az eltérô szocializációs életútjuk, az eltérố kommunikációs lehetôségeik vagy szokásaik miatt - bár még körükben is nagyon fontos a közösségi oldalak e funkciója. A közösségi oldalak tematikus tájékozódásban betöltött szerepe viszont nagyon hasonló a vizsgált korcsoportokban, nincs statisztikailag igazolható eltérés közöttük.

Az információ-megosztás, azaz az internet-korszak és a közösségi oldalak elótti idószakból ismert „pletykálkodás” is fontos a közösségi oldalak használói számára. Az „érdekes dolgok" megosztása a közösségi oldalakon keresztül viszont egyértelmúen a középkorú és idôsebb korosztály által preferált módszer, a 40 év felettiek $26 \%$-a használja erre is a közösségi médiát, míg a fiatalabbak tartózkodóbbak e tekintetben. Korcsoportonként átlagosan 15, ill. 17\%-ban használják tartalommegosztásra a közösségi médiát.

A szakmai kapcsolatok építése és a szakmai tájékozódás terén sincs különbség a korosztályok között, szemben az álláskereséssel. Ahol korosztályi okokból nagyon is van. Miközben a 30 alatti korosztály 19\%-a számít a közösségi oldalak által nyújtott lehetôségekre is az álláskeresésben, addig a negyvenesek és idôsebbek már csak 8\%-ban építenek erre - feltehetốen azért is, mivel kevésbé van rá szükségük, akár meglévố stabil állásuk, vagy kiterjedt szakmai kapcsolat-hálózatuk miatt, akár mert már vagy nem akarnak váltani, vagy nyugdíjba vonultak. 


\begin{tabular}{|c|c|c|c|c|}
\hline $\begin{array}{c}\text { családtagokkal, barátokkal, } \\
\text { ismerósökkel való } \\
\text { kapcsolattartás személyes } \\
\text { információk megosztásán és } \\
\text { követésén keresztül }\end{array}$ & 18-29 évesek & $30-39$ évesek & $\begin{array}{c}\text { 40 évesek és } \\
\text { idósebbek }\end{array}$ & Átlagosan \\
\hline $\begin{array}{c}\text { követem a számomra érdekes } \\
\text { témákkal foglalkozó } \\
\text { oldalakat, tájékozódom } \\
\text { ezeken }\end{array}$ & $62 \%$ & $91 \%$ & $86 \%$ & $89 \%$ \\
\hline $\begin{array}{c}\text { tágabb körben megosztani a } \\
\text { számomra érdekes dolgokat }\end{array}$ & $17^{\circ} \%$ & $15 \% \%$ & $63 \%$ & $21 \%$ \\
\hline $\begin{array}{c}\text { szakmai kapcsolatok } \\
\text { építésére, fenntartására }\end{array}$ & $19 \%$ & $18 \%$ & $15 \%$ & $17 \%$ \\
\hline $\begin{array}{c}\text { szakmai tájékozódásra } \\
\text { jelenlegi/késóbbi } \\
\text { álláskeresésre, vagy, hogy ott } \\
\text { megtaláljanak állásajánlattal }\end{array}$ & $16 \%$ & $11 \%$ & $12 \%$ & $13 \%$ \\
\hline
\end{tabular}

4. táblázat „Milyen célra használja a közösségi oldalt, oldalakat?”

Forrás: eNET online kutatás, 2015. április, VeVa online kutatási közösség,

N=963, 18+ internetezố és közösségi oldalakat használó; az egyes funkciókat használók százalékos aránya a felnốtt magyar internetezó és közösségi oldalakat követók körében korcsoportonként

\section{Az okostelefonok térhódítása megállíthatatlan}

Az okostelefonok hamarosan szinte egyeduralkodókká válhatnak az internetezók körében - ha tovább folytatódik a jelenlegi generációs trend, mivel minden új generáció nagyobb arányban választ okostelefont, mint az előzô. Míg a 40 éves és idôsebb korosztályban „csak” a netezók több mint fele használ ilyen készüléket, addig, a harmincasoknak közel nyolctizede, a 30 év alattiaknak pedig $87 \%$-a.

Az okostelefonok „továbbokosítására” szolgáló applikációk használatában is hasonló trend látható. Miközben a 40 feletti okostelefon-használóknak csupán egyharmada, a harmincasoknak pedig csak kicsit több, mint négytizede, a náluk is fiatalabbaknak viszont már 56\%-a tölt le legalább havonta egyszer alkalmazást.

Nemcsak a letöltött, de a rendszeresen használt applikáció-fajták száma is erôsen korosztályfüggó: a kutatás során vizsgált 15 applikáció-típusból a „kíváncsi” huszonévesek még átlagosan 3,7 alkalmazást használnak, a valamivel megfontoltabb harmincasok már csak 2,8-at, míg a jelen tanulmányban érdeklődési körük alapján ínyenceknek nevezett 40-es és idôsebb korosztály tagjai már egy sokkal szelektáltabb, átlagosan 1,6 alkalmazást tartalmazó készlettel is megelégszenek a rendszeres használat során. 
Az életkori sajátosságokból fakadó eltérő érdeklődési körök visszaköszönnek az applikációk kiválasztásában is. A legfeljebb 29 éves, alkalmazást letöltő fiatalok leginkább játszanak telefonjukon (72\%). Felük közösségi oldalakat, térkép és navigációs, zenével kapcsolatos és idôjárási adatokat szolgáltató alkalmazásokat használ. A harmincasok esetében a sorrend némileg eltér, de a top5 ugyanezen alkalmazásokat jelenti. 40 felett a zene veszít fontosságából, helyét a hírolvasás veszi át. Általánosságban fontos, hogy az alkalmazás ingyenes legyen, könnyen áttekinthetô felülettel rendelkezzen, kialakítása esztétikusnak hasson. Az alkalmazás magyar nyelvú elérhetôsége a kor emelkedésével válik egyre fontosabbá.

\section{Fiatalok: otthon az online közösségi térben}

A fiatalok egyre inkább az online világban találják meg azokat a tartalmakat, amiket szívesen fogyasztanak (olvasnak, hallgatnak, néznek). Számukra a hagyományos médiumok (tévé, rádió) leértékelődtek, feltehetóen azért, mert személyre szabott és bármikor elérhetố tartalmat keresnek. Nem ók akarnak alkalmazkodni a médiához, hanem a médiától várják el, hogy alkalmazkodjon hozzájuk. Változott a hozzáállásuk a tartalomhoz is, nemcsak fogyasztják, de szívesen meg is osztják azt, és egyáltalán nem csak anyagi okokból, hanem sok esetben pusztán érdekesség vagy spontán „terméktámogatás” miatt. Vagyis a fiatalok az interneten nemcsak tartalmat fogyasztanak, de kommunikálnak, megosztanak, tartalmat továbbítanak - ezáltal közösségi teret hoznak létre, amivel ma már mindenkinek számolnia kell.

\section{Befejezés: nem csak a húszéveseké a világ}

A fiatalok médiafogyasztásával és az új kommunikációs eszközök használatával kapcsolatban az egyik legfontosabb kérdés - amire talán a legnehezebb válaszolni -, hogy a mai fiatalok jelentik-e a jövoót? Tehát, amit a mai fiatalok csinálnak, az válik-e általánossá késóbb? Az általuk képviselt változás elterjed-e az egész társadalomban? Jeffrey Cole médiakutató az ezredfordulón azért indította útjára a globális World Internet Projectet (WIP - egy eredetileg tíz évre tervezett, internetezési szokásokat vizsgáló nemzetközi összehasonlító kutatást, ami mind a mai napig fut), mert évtizedek óta elôször az ezredforduló elótt elkezdett csökkenni a legfiatalabbak tévé elótt töltött ideje az USA-ban - az internet hatására. Ezt egyrészt olyan intố jelnek tekintette, ami forradalmi változások elószele lehet a médiafogyasztásban (ma már tudjuk, hogy igaza lett), másrészt felcsillantotta a lehetôségét annak, hogy valós idóben, folyamatos, évról-évre folyó kutatásokkal dokumentáljuk ezt a változást, ha már arról lemaradtak annak idején a kutatók, ahogy a televízió elterjedt a modern társadalmakban, gyökeres változásokat hozva például a szabadidő eltöltésében vagy a társadalmi kapcsolatokban (Putnam, 2000). Nem véletlen, hogy az internet kapcsán már az elsó, 2000-ben megjelent WIP riportban külön fejezet szólt arról, hogy az internet egy generációt definiáló technológiává válhat (Lebo, 2000: 3). ${ }^{8}$

8 "We focus on these broad issues in the first UCLA Internet Report, as we begin our year-to-year study of what may be the defining technology of our generation." (Lebo, 2000: 6) 
Ugyanakkor az is igaz, hogy annak ellenére, hogy évtizedek óta kongatják a vészharangot a televízió és a televíziónézés fölött, az köszöni szépen, de jól van, még ha folyamatos változásban is. És az is igaz - fóleg az öreg kontinensen -, hogy a mondás, ,jönnek a fiatalok" egyre erốtlenebbül hangzik egy elöregedô Európában. Valójában inkább arról kellene beszélnünk, hogy „jönnek az öregek” - pláne, hogy ahogy az Magyar Ifjúság 2012 kutatás is jelezte (Székely, 2013), a mostani fiatalok inkább csendesek és visszahúzódók, inkább teret adnak másoknak, mintsem, hogy magukat helyezzék az elôtérbe.

Mindez arra int minket, hogy ne gondoljuk, a fiatalok szokásai egy az egyben felfoghatók, mint a jövố elóképei. A fentebb, általunk bemutatott, 18-29 évesekre jellemzố eredmények túlzó általánosításától, vagy jövoóképként való elơrevetítésétól azért is óvnánk, mert egész biztos, hogy a fiatalok médiafogyasztása és technológia használati szokásai is változnak idôvel, ahogyan felnốnek majd öregszenek (Pintér-Székely, 2006). Ennek legalább három jól körülhatárolható oka van, bár az is igaz, hogy nem egyértelmúen egyetlen irányba mutatnak ezek a változások (vagyis további empirikus kutatásra volna szükség ezekkel kapcsolatban, aminek elvégzésére buzdítunk minden hazai empirikus kutatót, aki érdeklő́dik a téma iránt):

- saját, önálló háztartásba költözés, ami kevésbé felszerelt a legújabb technológiákkal, drága média vagy távközlési eloófizetésekkel, mint a szülő́i háztartás volt;

- munkába állás, amitól lecsökken a médiafogyasztásra fordítható szabadidô, bár ezzel együtt megnốnek az anyagi lehetôségek, tehát nôhet például az eszközökkel való ellátottság;

- saját család alapítása, amitốl lényegesen lecsökkenhet a tévénézésre fordítható szabadidó, bár ezzel ellentétesen hat, hogy ezzel párhuzamosan megnố az otthon ülés aránya, ami kiváló táptalaja például a tévézésnek.

Az egymásnak ellentmondó hatások dacára egyvalami azonban biztos, a mai fiatalok is lesznek öregebbek és jönnek a még fiatalabbak - ezzel együtt pedig folyamatos változásban lesz a médiafogyasztás, valamint a különbözó technológiai eszközök használata idehaza is. Egyelốre egyáltalán nem túnik úgy, hogy ezek a változások lassulnának vagy az új média és az új kommunikációs technológiák jelentette innovációk kevéssé lennének meghatározóak a fiatalok életében. De legalább ez az egy dolog állandónak tekinthetố egy változásokkal teli világban.

\section{Irodalom}

Howe, Neil - Strauss, William (1991): Generations: The History of America's Future, 1584 to 2069. New York: William Morrow \& Company.

Lebo, Harlan (2000): THE UCLA INTERNET REPORT - Surveying the Digital Future. UCLA Center for Communication Policy. http://www.worldinternetproject.net/_files/_Published/_ oldis/ucla-internet1.pdf Újra letöltve 2015. szeptember 5.

Nagy Bandó András (1986): Hanyas vagy. Nyíregyháza Városi Televízió, 1986. január 13. http://www.mzsk.hu:8123/?docId=93939 Letöltve 2015. szeptember 4.

Pintér Róbert - Székely Levente (2006): Bezzeg a mai fiatalok - a tizenéves korosztály médiafogyasztása a többségi társadalom tükrében. In: Internet.hu - A magyar társadalom digitális gyorsfényképe 3, Tárki Zrt., 137-160. 
Putnam, Robert D. (2000): Bowling Alone: The Collapse and Revival of American Community. New York: Simon \& Schuster.

Székely Levente szerk.(2013): Magyar Ifjúság 2012 Tanulmánykötet. Kutatópont, Budapest.

Székely, L. (2014): Az új csendes generáció. (in: Nagy, Á. - Székely, L. (szerk.): Másodkézból Magyar Ifjúság 2012. ISZT Alapítvány-Kutatópont. 9-28.)

Szilágyi György: Hanyas vagy? Elốször elhangzott a Kossuth rádióban 1976. december 3-án. http://www.szepi.hu/irodalom/vers/tvers/tv_089.html Letöltve 2015. szeptember 4. 